\title{
MODERN MYTH: DEMYSTIFICATION INSTRUCTIONS FOR PEDAGOGUES
}

\begin{abstract}
Ukrainian informational space has been deeply damaged by centuries old colonial policy - myths have been deliberately distorting and depreciating Ukrainian history and culture. Under conditions of informational aggression together with governmental informational policy, keeping to ethics provided by mass media pedagogue has an important mission of society demythologization.

Purpose. This article aims to consider the modern myth as an object of scientific research and pedagogical problem, to name the causes and stages of society mythologization, to classify the myths and to name their functions. This article also aims to propose a technique of psychological and pedagogical influence, aimed at demystifying the worldview - a metamodel of neurolinguistic programming.

Methods. Analysis and generalization of scientific sources and documents have been performed. Deduction technique has been applied as a process of drawing logical conclusion based on the complex of analyzed facts and summarizing.

Conclusions. The main reasons why myths arise are absence of knowledge and misunderstanding of facts, hiding truth, herd mentality, striving for unity and selfdeception. Therefore, we propose to implement the work on demythologization according to the following stages: 1) myth identification, 2) determination of myth characteristics, 3) scientifically substantiated refutation of myth, 4) psychological and pedagogical activities aimed at transforming the mythical worldview. Special attention should be paid to the function which every myth performs: rational, adaptive, security function, mobilizing function, function of history legitimization or means of mass consciousness manipulation. Correct identification of every particular myth and its characteristics will provide finding the most effective pedagogical methods and technologies of demythologization.
\end{abstract}


KEYWORDS: myth, mythologization, reasons of myths' appearance, stages of mythologization, myth' classification, functions of myths, demythologization

\section{INTRODUCTION}

Mythology occupies unique place in the system of spiritual values of humanity - as inseparable part of culture archaic myth contains a sort of program of civilization evolution. Modern myth is strenuously politicized - its functionality comes to the first place - ability to unite people, direct political energy and manipulate. Political mythology substitutes reality, distorts it as it doesn't affect mind, but emotions.

Starting from the XIX th century mythological problems have been an object for research of philosophers, psychologists, theologians, linguists, sociologists, politologists and others. In modern world of informational wars myth as an object of scientific research hasn't still lost its positions. In particular, Pavel Gurevich [Gurevich 1983; Gurevich 1997], Jeleazar Mieletinski [Meletinskiy 2012], Kurt Hübner [Hübner 1985], Janusz Sztumski [Sztumski 2004] investigated myth as social phenomenon; Lubmyla Zubrytska [Zubrytska 2005], Władysław Szostak [Szostak 2010] - as a phenomenon of contemporary politics; Jerzy Jaskiernia [Jaskiernia 2010] studied the role of myths in the process of European integration; Marzena Cichosz [Cichosz 2010] considered creation of Polish politicians images by means of myth-making. Giovanni C. Cattini investigates basic influence of myths on political culture of Catalan nationalism [Cattini 2015]; Maribel Fierro considers political myths as one of the sources of literary tropes on reign [Fierro 2015]; Dan Naor investigates evolution of oppression myth [Naor 2006]; Vincent Della Sala analyses myth as a means of society solidarity in the European Union [Della Sala 2015] etc.

Ukrainian informational space is deeply damaged by centuries old colonial policy. Myths and stereotypes have been purposefully depreciating Ukrainian history and culture.

An important point is that Russian anti-Ukrainian aggression is largely based on history mystification. According to Mykola Davydiuk [Davydiuk 2016: 176], pro-Russian political parties in Ukraine, as well as pro-Russian 
separatist and terrorist groups in the occupied territories of Donbas and Luhansk region, have chosen "nostalgia for the Soviet Union" as their main ideological weapon. After all, never being able to offer a sound socioeconomic reform package or a modern program, they all speculate on the supposedly best years of the Soviet Union period, availability of jobs and the cheapness of certain goods typical for that time.

It should be noted that the use of history for ideological and propaganda purposes in Russia has a long tradition. This process is based on creating and spreading historical myths which in fact replace objective historical knowledge.

The main myths aimed at reproduction of the Russian imperialism include:

- mythologized history of the so called Ancient Rus (this term is now being introduced in the Russian information space instead of previously used "Kyivan Rus"), and this gives the start for another myth - about the common origin of Russians, Ukrainians and Belarussians;

- the civilizational greatness of the pre-revolutionary Russian Empire;

- multiculturalism - combining history and culture of all nations which at different stages were parts of the Russian Empire, into a single civilization of the "Russian world";

- victory (in fact - individual) over Nazi Germany as well as "liberation" and "salvation" of Europe and European civilization;

- world leadership and opposition to the Western camp in the Cold War, a bipolar world in which one of the politic poles was presented by Russia in the image of the USSR;

- revival of the Russian Empire after a "pernicious" period of "false" orientation to liberal valuesi [Zdioruk et al. 2017: 136], etc.

Under such conditions, in the world overloaded by distorted facts, disinformation and other informational manipulations, mission of a teacher gains significance which is hard to overestimate. Pedagogue being aware of true facts, thinks critically and is able to teach others skills of logical analyses, who is able and even morally obliged to do his best to enable demythologization of the society. And this is a great challenge for the pedagogue. 
Experience has shown that the process of demystification should be carried out comprehensively with the use of information and educational method alongside with the method of individual psychological influence. We propose to implement the following stages in this activity:

1. Myth identification.

2. Determination of myth characteristics.

3. Scientifically substantiated refutation of myth

4. Psychological and pedagogical activities aimed at transforming the mythical worldview.

This article aims to consider the modern myth as an object of scientific research and pedagogical problem, to name the causes and stages of society mythologization, to classify the myths and to name their functions. This article also aims to propose a technique of psychological and pedagogical influence, aimed at demystifying the worldview - a metamodel of neurolinguistic programming.

\section{StAgE 1. MYth IDENTIFICATION}

\section{Notion of Myth Definition}

Manifestations of mythological outlook are an inseparable part of modern culture. Scientific literature considers it as an alternative to logical, scientific thinking, based on facts and employs the term of "modern myth", "neomyth" or a "pseudo-myth".

In modern literature the notion of "myth" (from Greek mythos - a legend, belief accepted without any proofs) is characterized by complete polysemy. In traditional understanding myth is a story, which arises at early stages of human development, in the myth natural and cultural phenomena appear in spiritualized and personal forms. In later interpretation it is a historically conditioned type of social consciousness. In recent definitions by myth they understand uncritically perceived view. Myth is evaluated as a universal way of human worldview.

Myth differs from metaphor and symbol by the fact that everything is understood literary and realistically in myth. Myth is a certain form of 
consciousness, worldview which is supposed to explain mysteries and the phenomenon of reality. Myth is perceived as reality, which doesn't require evidence, justification and verification - everything is taken at face value, without doubts.

By myth Jeleazar Mieletinski understands illusion, falsity, propaganda, sacred expression of social customs and values. Besides, by myth one can understand a judgment which is not based on sensory experience and which doesn't coincide with objective reality; information which is perceived without evidence and rational comprehension [Meletinskiy 2012].

Following Janusz Sztumski in this work we accept the following definition of myth. Myth is the product of certain way of thinking (along with common sense and magical thinking), which appeared as a result of certain way of human's intellectual development. It is characterized by considerable ability abstraction, which is revealed in distinguishing of what can be lived through by senses and what can be thought about [Sztumski 2004: 321].

Marzena Cichosz points to peculiar features which distinguish myth from other phenomena. The first one is that the myth is connected with particular community, it is firmly stemmed in traditions and group's culture - i.e. myth defines community's identity. The second feature is that the myth has prophetic and eschatological nature [Cichosz 2010: 366].

Myths can be seen in different spheres of life and in different situational contexts. The very idea of myth relates to the past, present and future. The myth educates, points to and taboos certain spheres of the reality. It can be based on the knowledge, which can not always be true, as well as stereotypical and ordered with dominating narrative samples, but in fact it relates to the future [Jaskiernia 2010: 92].

\section{Stages of Mythologization}

We now single out three stages of mythologization. The first one is myth creation, which is the kind of spiritual production of a society and therefore defined as spiritual-practical and theoretical activity aimed at production of spiritual values - social myths.

The second stage is implementation of certain idea and outlined algorithm of political behavior into mass consciousness, which at definite moment will 
affect the process of making proper political decision. Main role at this stage is played by the mass media. Implementation is based on the visualization principle, "what has been pronounced is almost happening".

The third stage of mythologization of the society is expansion of the myth in the process of authorities communication with citizens. There manipulative function of political myth is fulfilled. One can consider famous statement of Goebbels claiming that lie repeated thousand times becomes truth to be its first stage.

Consequence of mythologization is detachment from the reality - a person enters mythical world which suits him or her better than the reality.

On the ability to define mythologization stage correctly depends correspondence of chosen by him methods of demythologization. At the first stage one should mainly work on the reasons of mythologization. At the second stage it is necessary to teach how to recognize and search authentic sources of information as well as logical analyses. At the third one main role belongs to teaching of critical thinking.

\section{StAgE 2. DETERMINATION OF MYTH CHARACTERISTICS}

\section{Reasons for Myths Appearance}

Modern myths mainly arise as a response to the society's demand in accordance with available values and ambitions. Among the main reasons for myths appearance we define the following ones:

1) absence of exact knowledge (misunderstanding) of certain phenomena, problems, events. Without having precise facts person creates certain cause and effects relationships, combines uncharacteristic peculiarities;

2) concealment of truth;

3) pack-running, striving for unity;

4) self-deception whose aims are:

- self-affirmation,

- creation of inner comfort

- minimization of real life efforts.

Understanding reasons of a certain myth appearance is of particular importance for a pedagogue as success of demythologization mostly depends 
on this. If the reason is absence of lack of knowledge the mission of a teacher is to provide this knowledge.

When pedagogy understands that the reason of myth's appearance is an intention to hide the truth the mission of the teacher is to teach students to reveal truth and how to be able to be able to find authentic sources of information formulate logical conclusions.

In case of pack-running effect pedagogue's task is to teach and motivate independent thinking, not taking unverified facts at face value, to cultivate critical intellectual individualism of thinking.

If the reasons of myth creation are various kinds of disguised complexes of a person, the pedagogue's task is to clarify these complexes with the help of psychological support and work to overcome them.

\section{Myths Classification}

Although modern myths became object of scientific studies long ago, there hasn't been still established any single and unified system of myths classification. Among the variety of classifications, we'll single out classifications of Kurt Hübner and Pavel Gurevich.

According to sources of creation, Kurt Hübner divides myths into the "myths proper" and "pseudo-myths" [Hübner 1985]. Myths proper arise naturally in people's consciousness, which is occupied unobtrusively. Pseudomyths Kurt Hübner equals to ideology - outlook, aggressively imposed with the aim to achieve goals defined by ideologists.

According to Pavel Gurevich classification, all myths develop two supreme plots. The first one is the idyll myth, "search for benevolent rescue utopia". The second reveals forces of the evil and demonstrates catastrophism technique and evil fate - this is myth-horror. Idylls bring good while the reality is horrible. But people in their behavior not always follow inspiring truth, they are more delighted by chimera and horror which are not correlated with the truth as it is [Gurevich 1997: 409].

Admitting the fact that myth is a kind of social consciousness and taking into consideration different approaches to the consciousness structuring the myth system can be featured in the form of Table 1 . 
On correct reference of a myth to a certain group depends effectiveness of special knowledge, abilities and skills application in pedagogical activity aiming at refutation of a particular myth.

\section{Table 1. Myths classification}

\begin{tabular}{|c|c|}
\hline Principles of Myths Classification & Myths Types \\
\hline \multirow{4}{*}{ according to historical epochs } & myths of the Ancient World \\
\hline & Middle Ages myths \\
\hline & Modern History myths \\
\hline & Contemporary History myths \\
\hline \multirow{2}{*}{$\begin{array}{l}\text { according to the source of creation } \\
\text { (Kurt Hübner) }\end{array}$} & myths proper \\
\hline & pseudo-myths \\
\hline \multirow{4}{*}{ according to the type of bearer } & individual myths \\
\hline & group myths \\
\hline & social myths \\
\hline & universal myths \\
\hline \multirow{7}{*}{ according to the sphere of activity } & economical myths \\
\hline & ecological myths \\
\hline & legal myths \\
\hline & political myths \\
\hline & myths of moral sphere \\
\hline & myths of aesthetic sphere \\
\hline & religious myths \\
\hline \multirow{2}{*}{ according to the level of penetration into reality } & myths of practical level \\
\hline & myths of theoretical level \\
\hline \multirow{2}{*}{$\begin{array}{l}\text { according to emotional content } \\
\text { (3a Pavel Gurevich) }\end{array}$} & myths idylls \\
\hline & Myths-horrors \\
\hline
\end{tabular}

Source: author's own elaboration. 


\section{Myths Functions}

Myths perform many social functions, most important of which are the following [Jaskiernia 2010; Meletinskiy 2012; Szostak 2010; Sztumski 2004; Zubrytska 2005]:

1) rational (substitution of knowledge) - myth justifies certain behavior, facts, means of acting [Szostak 2010: 24]. In manifestation of this function Pavel Gurevich [Gurevich 1983: 97] has noticed paradoxical dependence: the more illusory certain statement is, the more actively the work of thought which assigns visibility of extended truth to this statement is performed;

2) adaptive (group adaptation) - myth contains the whole complex of elements, necessary for normal life activities of the society in accordance with laws, implicitly expressed in the myth;

3) security function (enemy/counterpart identification) [Szostak 2010: 24];

4) mobilization function: in Georges E. Sorel's opinion, one can talk about rebellion as much as he wants and not awaken any revolutionary movements, - and all this is due to absence of myth accepted by the masses [Sorel 2004];

5) legitimization of history;

6) means of manipulation by mass consciousness - in mythologized individual the ability to think critically reduces, the individual is "depersonalized" and becomes a part of mass. Respectively, contemporary myths gradually lose their positive functions, transforming into

Rational function was the leading one for classical myths - at early stages of humanity development lack of knowledge about surrounding world society compensated by mythical outlook. Now, when mass media fabricate countless number of myths - function of myth as a way of mass consciousness manipulation has become the paramount one.

Depending on the function performed by the myth within pedagogical work on aimed at specific myth refutation one should select appropriate methods and means of psycho-pedagogical influence. Among them are providing appropriate knowledge, critical thinking development, work with psychological complexes etc. 


\section{STAGE 3. SCIENTIFICALly SUBSTANTIATED REFUTATION OF MYTH}

The main principle and complexity of demythologization is that each myth should be considered separately - i.e. the refutation and debunking of each particular myth is a separate full-fledged scientific research carried out using logical methods of scientific knowledge and scientific research methods.

There is a belief that myths live in the public consciousness until they can be publicly refuted so impressively that it could be effective (it is about influencing public opinion on a massive scale) [Jaskiernia 2010, 108-109]. However experience has shown that that the most socially significant, but at the same time a more difficult way to combat myths consists in education and socialization. [Szostak 2010, 29-30].

Russia’s anti-Ukrainian aggression, followed by military action, has significantly intensified public awareness in Ukraine and exposed the need to actively disseminate truthful information about events in Ukraine and refute the information disseminated by Russia. For this purpose numerous public organizations have emerged, and numerous educational websites and social media pages have been created. LIKBEZ is one of such projects. It is a project created by a group of Ukrainian volunteer historians. The purpose of this project consists in scientifically substantiated debunking of myths and stereotypes about Ukraine and its history.

"Of course, we cannot stop the wave of Putin's propaganda; it is incompatible resources and scale. We will not reach the mind of every Ukrainian who has been zombified by Russian television. Our resource is for those people who are looking for a reliable source to be able to form their position based on competent historical information, as well as to be able to justify this position" - says project coordinator Kirill Galushko. In the process of information struggle against Russian political mythologization, the LIKBEZ website provides scientifically sound explanations of historical reality - these are articles in which the authors clearly and easily debunk Moscow myths.

A number of scientific developments refuting certain myths, exposing the negative impact of myths on the society and revealing the elements of demystification technology were also created by the author of this work within her own scientific research. These developments without limitation 
include the following: "The Russian-language Wikipedia as a Measure of Society Political Mythologization” [Sokolova 2017], “Technology of Soviet Myth Creation about Famine as a Result of Crop Failure in Ukraine of the 1932-1933s" [Sokolova 2019-b], "Formation of Alternative Reality in Totalitarian Society: mythologization of Chornobyl Catastrophe in 1986" [Sokolova 2019-a], “Tourism as a method of direct demystification" [Sokolova 2020], "Application of Rationale and Argumentation in Refuting Up-to-date Myths and Stereotypes" [Sokolova, 2019-c], "Violations of Comparative Method Application within Internet Discussions of Fiction" [Sokolova 2018] etc.

\section{Stage 4. WORLDVieW Demythologization by means of Neurolinguistic Programming}

The difficulty of demystification consists in the fact that people being "impressed" by the mythical worldview perceive only what is confirmed by their existing ideas and they "do not see" anything that contradicts their beliefs. Therefore, in itself, a scientifically substantiated myth refutation in itself can be perceived by such a person as something hostile and distrustful. Thus, the task of a person who aims to demystify interlocutor's worldview can be compared with the task of a psychoanalyst - this task is to show that the horizon is wider than in the world created by the myth. Therefore, some models of psychoanalytic activity are worth to be used. In this context methods and techniques of neurolinguistic programming deserve special attention. Modeling technique is one of such techniques.

While speaking a person automatically and continuously participates in three processes - distortion, simplification and deletion. Distortion changes reality in such a way that people say, see and remember things which are actually different. Generalization (simplification) describes things in such a way that everyone should experience everything in the same way as the speaker. During generalization unusual situations and possible exceptions to the rule are ignored. Generalized statements often contain words such as "all", "everyone", "always" and "never". On the other hand, deletion is the omission of certain details, which leads to incompleteness of the presented image of reality [Churches, Terry 2010: 164]. 
Taking into account the abovementioned processes, a practical metamodel of psychological influence has been created in practical psychology; this metamodel consists in use of language templates. The metamodel consists of questions interconnected through the template; these questions are an effective tool for combating distortions, generalizations, and deletions. The questions are intended to recover information omitted through the use of generalizations, distortions, and deletions.

A properly formulated question can affect person's way of thinking [Churches, Terry 2010: 161-162]. Such questions encourage people to more complex thinking processes than those usually practiced in the mythological worldview. Therefore, a demystifying person must always anticipate what he or she expects when asking a certain type of questions, and such person must clearly understand his or her purpose.

If the demystifier notices presence of a metamodel in statements of his/ her interlocutor with a mythical worldview, he/she should ask questions that will restore the details missed by interlocutor's consciousness. It is then that the demystifier will be able to help his/her interlocutor to see the world from a different perspective.

The main questions of the metamodel are:

1. When noticing a deletion, ask: Could you please tell me more about this...?

2. When noticing a generalization, ask: Does this always happen?

3. When noticing a distortion, ask: How do you know that..? [Churches, Terry 2010: 166].

As an example of applying the described neurolinguistic programming metamodel I offer the following language templates for modeling the antiUkrainian mythical worldview [Table 2].

Based on the standard metamodel proposed by R. Churches and R. Terry an experienced pedagogue is a able to develop his/her own set of questions and techniques for use in individual conversations aimed at demythologizing the worldview of students. 
Table 2. Language Templates for Modeling the anti-Ukrainian Mythical Worldview

\begin{tabular}{|c|c|c|c|}
\hline \multicolumn{2}{|c|}{ Metamodel } & Example & Question \\
\hline \multirow{5}{*}{$\begin{array}{l}\text { Deletion } \\
\text { Find out what } \\
\text { is behind the } \\
\text { words. }\end{array}$} & \multirow[t]{2}{*}{$\begin{array}{l}\text { The main } \\
\text { deletion }\end{array}$} & $\begin{array}{l}\text { In Ukraine the Russian } \\
\text { language is being suppressed. }\end{array}$ & $\begin{array}{c}\text { What is the exact way } \\
\text { of suppressing the Russian } \\
\text { language in Ukraine? }\end{array}$ \\
\hline & & $\begin{array}{l}\text { Nobody is waiting for Ukraine } \\
\text { in the European Union. }\end{array}$ & $\begin{array}{l}\text { Who exactly is not waiting for } \\
\text { Ukraine in the European Union? }\end{array}$ \\
\hline & $\begin{array}{l}\text { Comparative } \\
\text { deletion }\end{array}$ & $\begin{array}{l}\text { The political system in } \\
\text { Russia is better than those in } \\
\text { other countries. }\end{array}$ & And why exactly is it better? \\
\hline & $\begin{array}{l}\text { Indefinite } \\
\text { verb }\end{array}$ & $\begin{array}{l}\text { Ukrainians betrayed } \\
\text { Russians. }\end{array}$ & $\begin{array}{c}\text { How exactly did Ukrainians } \\
\text { betray Russians? }\end{array}$ \\
\hline & $\begin{array}{c}\text { Lack } \\
\text { of a standard }\end{array}$ & $\begin{array}{l}\text { Russia and Ukraine must } \\
\text { be a single country. } \\
\text { All Ukrainians are betrayers. }\end{array}$ & $\begin{array}{l}\text { Who says that? } \\
\text { Who exactly betrayed and who } \\
\text { exactly was betrayed? }\end{array}$ \\
\hline \multirow{5}{*}{$\begin{array}{l}\text { Distortion. } \\
\text { Semantic } \\
\text { mistakes should } \\
\text { be separated! }\end{array}$} & $\begin{array}{l}\text { Nominaliza- } \\
\text { tion }\end{array}$ & $\begin{array}{l}\text { Independence of Ukraine } \\
\text { is a misconception. }\end{array}$ & $\begin{array}{c}\text { What should be, in your opinion, } \\
\text { the status of Ukraine in the } \\
\text { international sphere? }\end{array}$ \\
\hline & Supposition & $\begin{array}{l}\text { If you understood what is } \\
\text { related with this, you would } \\
\text { not doubt my words. }\end{array}$ & $\begin{array}{l}\text { Why do you say that I don't } \\
\text { understand what is going on? }\end{array}$ \\
\hline & $\begin{array}{c}\text { Cause } \\
\text { and effect }\end{array}$ & $\begin{array}{l}\text { These Ukrainians irritate me } \\
\text { so much. }\end{array}$ & $\begin{array}{l}\text { What are their actions you are } \\
\text { irritated through? }\end{array}$ \\
\hline & $\begin{array}{l}\text { Complex } \\
\text { equivalence }\end{array}$ & $\begin{array}{l}\text { They have imposed } \\
\text { economic sanctions on } \\
\text { Russia, so they hate us. }\end{array}$ & $\begin{array}{l}\text { Had anybody imposed economic } \\
\text { sanctions on Russia before? }\end{array}$ \\
\hline & Mind reading & Her problem is that she thinks... & How do you know about this...? \\
\hline \multirow{5}{*}{$\begin{array}{l}\text { Generalization } \\
\text { Put into } \\
\text { question the } \\
\text { world map of } \\
\text { other people. }\end{array}$} & \multirow{2}{*}{$\begin{array}{l}\text { Modal verbs } \\
\text { expressing } \\
\text { necessity }\end{array}$} & We must do it in this way. & $\begin{array}{l}\text { What would happen if we acted } \\
\text { differently? }\end{array}$ \\
\hline & & We really mustn't ... & What would happen if we did this? \\
\hline & $\begin{array}{l}\text { Modal verbs } \\
\text { expressing } \\
\text { possibility }\end{array}$ & Russia cannot allow... & $\begin{array}{c}\text { What could your country achieve } \\
\text { if you could do it? }\end{array}$ \\
\hline & $\begin{array}{c}\text { General } \\
\text { quantifiers }\end{array}$ & $\begin{array}{l}\text { All countries around Russia } \\
\text { are enemies }\end{array}$ & Are all countries really enemies? \\
\hline & $\begin{array}{l}\text { Executor's } \\
\text { omissions }\end{array}$ & $\begin{array}{l}\text { Ukrainians are just unable to } \\
\text { run the country. }\end{array}$ & $\begin{array}{l}\text { Who says that Ukrainians are not } \\
\text { able to govern the state at all? }\end{array}$ \\
\hline
\end{tabular}

Source: Own development based on the metamodel proposed by R. Churches and R. Terry [Churches, Terry 2010: 166-169]. 


\section{Conclusions}

Myth is a means of mass consciousness manipulation, which is becoming a significant threat for the society. Under conditions of informational aggression, along with competent informational policy of the state, compliance with ethics of mass media work pedagogue possesses an invaluable mission of reporting truthful information to the society and refutation of manipulations and disinformation. Therefore, investigation of modern myth phenomenon as an important and topical problem of pedagogical science crucial nowadays.

Teacher should always remember that main reasons of myths arising are absence of knowledge, misunderstanding of facts, concealment of the truth, pack-running, starving for unity, and self-deception. Correct identification of every myth and its characteristics will allow selecting the most effective pedagogical methods and technologies of demythologization.

In a perspective view further development of this issue should be directed to indicating new methods of pedagogical demystification of social consciousness.

\section{Bibliography}

Cattini, G.C. (2015). Myths and symbols in the political culture of Catalan nationalism (1880-1914). Nations and Nationalism, 21(3), pp. 445-460. ISSN 1354-5078.

Churches, R., Terry, R. (2010). NLP dla nauczycieli: Szkoła dla efektywnego nauczania. Gliwice: Onepress, 281 s. ISBN 9788324617579.

Cichosz, M. (2010). Przemiana w Herosa: Kreowanie wizerunków polskich polityków. W: Mity i stereotypy w polityce: Przeszłość i terazniejszość. Pod red. Agnieszki Kasińskiej-Metryki i Michała Gołosia; Polskie Towarzystwo Nauk Politycznych. Toruń: Wydawnictwo Adam Marszałek, ss. 365-377. ISBN 9788376115658.

Davydiuk Mykola. (2016). How Does Putin’s Propaganda Work? Kyiv: Smoloskyp. 200 p. ISBN 9786177173600.

Della Sala, V. (2015). Europe's odyssey?: political myth and the European Union. Nations and Nationalism, 22(3), pp. 524-541, DOI:10.1111/nana.12159. ISSN 1354-5078.

Fierro, M. (2015). Two Castilian political myths and al-Andalus. Journal of Medieval Iberian Studies, vol. 7, Issue 1, pp. 18-43. ISSN 1754-6567. 
Gurevich, P.S. (1983). Sotsial'naya mifologiya [Social Mythology]. Moscow: Mysl'. (in Russian).

Gurevich, P.S. (1997). Filosofskaya antropologiya [Philosophical Anthropology]. Moscow: Vestnik. (in Russian).

Hübner, K. (1985). Die Wahrheit des Mythos. München: Verlag C.H.Beck. ISBN 3406307736.

Jaskiernia, J. (2010). Rola mitów i stereotypów w procesie integracji europejskiej. Mity i stereotypy w polityce: Przeszłość i terazniejszość. Pod red. Agnieszki KasińskiejMetryki i Michała Gołosia; Polskie Towarzystwo Nauk Politycznych. Toruń: Wydawnictwo Adam Marszałek, ss. 92-109. ISBN 9788376115658.

LIKBEZ: istorychnyy front [The Historic Front]. Retrieved (17/05/2017) from: http:// likbez.org.ua/en

Meletinskiy, E.M.(2012). Poetika mifa. [Thepoetics of myth]. Moscow: Akademicheskiy Proyekt. (in Russian).

Naor, D. (2006). The Ehden massacre of 1978 in Lebanon: The creation of a resistance myth. The Journal of the Middle East and Africa, vol. 7, Issue 3, pp. 321-337. ISSN 2152-0844.

Sokolova, S. (2017). The Russian-language Wikipedia as a Measure of Society Political Mythologization. Journal of Modern Science, 33(2), pp. 147-176. ISSN 1734-2031.

Sokolova, S. (2018). Violations of Comparative Method Application within Internet Discussions of Fiction. Journal of Modern Science, 38(3), pp. 87-109. ISSN 1734-2031.

Sokolova, S. (2019a). Formowanie alternatywnej rzeczywistości w społeczeństwie totalitarnym: mitologizacja Czarnobylskiej katastrofy w 1986 roku. Journal of Modern Science, 41(2), pp. 39-60. DOI:10.13166/jms/110493. ISSN 1734-2031.

Sokolova, S. (2019b). Technology of Soviet Myth Creation about Famine as a Result of Crop Failure in Ukraine of the 1932-1933s. Journal of Modern Science, 42(3), pp. 37-56. DOI:10.13166/jms/113374. ISSN 1734-2031.

Sokolova, S. (2019c). Uzasadnianie i argumentowanie w komunikacji z osobami poddanymi mitom i stereotypom. Journal of Modern Science, 43(4), pp. 119-132. https://doi.org/10.13166/jms/117852. ISSN 1734-2031.

Sokolova, S. (2020). Turystyka jako metoda demistyfikacji bezpośredniej. Turystyka i Rozwój Regionalny, 13 (2020), pp. 139-149. ISSN 2353-9178.

Sorel, G. (2004). Reflections on violence. In Jennings, J. (ed.). Cambridge Texts of the History of Political Thought. Cambridge University Press. ISBN 9780511521317. 
Szostak, W. (2010). Mity i stereotypy w komunikacji politycznej. Mity i stereotypy $w$ polityce: Przeszłość i terazniejszość. Pod red. Agnieszki Kasińskiej-Metryki i Michała Gołosia; Polskie Towarzystwo Nauk Politycznych. Toruń: Wydawnictwo Adam Marszałek, ss. 21-30. ISBN 9788376115658.

Sztumski, J. (2004). Mit. Encyklopedia pedagogiczna XXI wieku. Tom III (M-O). Warszawa: Wydawnictwo Akademickie „Żak”, s. 1078. ISBN 9788389501240.

Zdioruk S.I., Lozovyj B.S., Pavlenko I.A., Stepyko M.T. (2017). Rekonstruktsiya impers'koyi identychnosti [Reconstruction of imperial identity]. Svitova hibrydna viyna: ukrayins'kyy front [The World Hybrid War: Ukrainian Forefront]. Kharkiv: Folio, 2017, $158 \mathrm{p}$.

Zubrytska, L.Y. (2005). Mif yak fenomen suchasnoyi polityky [Myth as a phenomenon of modern politics]. PhD Thesis. Kyiv: Taras Shevchenko National University of Kyiv. (in Ukrainian). 